\title{
SyrM1 of Rhizobium sp. NGR234 Activates Transcription of Symbiotic Loci and Controls the Level of Sulfated Nod Factors
}

\author{
Moez Hanin, Saïd Jabbouri, William J. Broughton, and Rémy Fellay \\ Laboratoire de Biologie Moléculaire des Plantes Supérieures (LBMPS), Université de Genève, 1 ch de \\ l'Impératrice, 1292 Chambésy/Genève, Switzerland \\ Accepted 29 January 1998.
}

\begin{abstract}
One or more transcriptional regulators of the LysR class control transcription of rhizobial nodulation genes. In Rhizobium sp. NGR234, two copies of nodD (nodD1 and nodD2) are present on the symbiotic plasmid pNGR234a. The complete sequence of pNGR234 $a$ revealed two additional nodD homologues, syrM1 and syrM2. Competitive RNA hybridization analyses involving a mutant of syrM1 (NGRAsyrM1) showed that a number of symbiotic genes (e.g., nolXBTUVW) are expressed in an syrM1-dependent manner. Assays in which regions upstream of nolB and nolW were fused to promotorless lac $Z$ confirmed that SyrM1 is required for their late induction. Mutation of syrM1 also drastically reduced production of sulfated Nod factors as shown by reverse phase-thin layer chromatography (RP-TLC). SyrM1 controls sulfation of Nod factors via one of the two chromosomal nodPQ loci. It thus seems likely that syrM1 of NGR234 encodes a transcriptional activator that regulates the expression of genes involved in both the early and late stages of infection.
\end{abstract}

A number of genera of gram-negative soil bacteria, collectively known as rhizobia, form nitrogen-fixing nodules on the roots of legumes. Sequential exchange of signals between the symbionts controls specificity in these associations (for recent reviews see Dénarié et al. 1996; Spaink 1996; Schultze and Kondorosi 1996; Mergaert et al. 1997; Hanin et al., in press). Flavonoids released by legume roots, in conjunction with rhizobial NodD proteins, activate transcription of nodulation genes (nod, nol, and noe). Enzymes encoded by the nod genes are responsible for the production and secretion of a family of lipo-chitin-oligosaccharides (LCOs) called Nod factors. Nod factors are $\beta-1,4$ linked tri- to hexa-mers of $N$-acetyl-Dglucosamine, which are $\mathrm{N}$-acylated at the nonreducing terminus (Lerouge et al. 1990). When transmitted to the host plant, these LCO messages trigger the initiation of nodule formation (Truchet et al. 1991; Relić et al. 1993b). Products of the $n o d A B C$ genes synthesize the core oligosaccharide, while enzymes encoded by host-specific nodulation genes direct decoration of the core molecule with various adjuncts.

Corresponding author: W. J. Broughton; LBMPS, 1 ch. de l'Impératrice, 1292 Chambésy/Genève, Switzerland; Telephone: 00412290617 40; Fax: 00412290617 41; E-mail: broughtw@sc2a.unige.ch
Transcriptional activation of nodulation genes by NodD appears to occur differentially in response to specific inducers (essentially flavonoids) derived from the roots of the various hosts. Correlations exist between the spectrum of flavonoids able to interact with NodD and promiscuity of nodulation. NodD proteins of narrow-host-range rhizobia such as Rhizobium meliloti and $R$. leguminosarum bv. viciae respond to a limited number of flavonoids while NodD1 of the broad-hostrange Rhizobium sp. NGR234 reacts with a large spectrum of inducing compounds, including simple phenolic substances (e.g., vanillin, iso-vanillin) as well as compounds that have been shown to be inhibitory in other rhizobia (Györgypal et al. 1991; Le Strange et al. 1990).

The number of copies of nodD is strain dependent, and in some cases one constitutively expressed gene activates the expression of the others (Fellay et al. 1998). NodD regulators belong to the LysR family of prokaryotic transcriptional activators (Henikoff et al. 1988). All possess a helix-turn-helix DNA binding motif in their $\mathrm{N}$ termini that is responsible for recognition of nod gene promoters (nod boxes). Attachment of the NodD-flavonoid complex to a nod box results in bending of the DNA, which is thought to be necessary for transcription of downstream nod genes (Fisher and Long. 1993). Activation of nod gene expression via nod-box promoters is not the only regulatory system used in rhizobia, however. The nolX gene of $R$. fredii USDA257 lacks a nod box, yet it is regulated in the conventional flavonoid- and nodD-dependent manner (Kovács et al. 1995; Bellato et al. 1996).

It should also be noted that additional positive and negative regulators of nod gene expression have been identified. In $R$. meliloti, syrM (a nodD homologue) along with nodD3 is involved in nod gene activation (Kondorosi et al. 1991a). nolR down-regulates transcription of nodD1, nodD2, and the nod $A B C$ genes by direct attachment to their overlapping promoters (Cren et al. 1995; Konodorosi et al. 1991b). By activating nodD2 of Bradyrhizobium japonicum, NolA leads to repression of nodulation genes (Garcia et al. 1996). B. japonicum also possesses another, unique, regulatory system (NodV/ NodW) (Sanjuan et al. 1994). NodV/NodW are members of the family of two-component regulatory systems. NodV is a sensor kinase that phosphorylates NodW, which is a response regulator (Loh et al. 1997).

Regulation of nod gene expression in NGR234 is poorly understood. Except for a few loci such as nodPQ (Perret et al. 
1991), most nodulation genes are grouped into several flavonoid-inducible loci on the large $(536 \mathrm{~kb})$ symbiotic plasmid pNGR234a (Fellay et al. 1995). Two copies of nodD (nodD1 and nodD2) are present: Mutation of nodD1 completely abolishes nodulation (Relić et al. 1993a). This is explained by the fact that, along with many others, nodABC is not transcribed in the nodD1 mutant (Fellay et al. 1995). nodD2, which is involved in repression of the $\operatorname{nod} A B C$ genes, is expressed in a nodD1-dependent manner, and is required for the formation of nitrogen-fixing nodules on roots of Vigna unguiculata and other NGR234 hosts (Fellay et al. 1998).

The complete sequence of pNGR234a (Freiberg et al. 1997) revealed 22 potential genes encoding transcriptional regulators. Among them, two copies of genes homologous to nodD were found: syrM1 and syrM2. The molecular and biochemical analyses presented here show that syrM1 is involved in activation of a number of symbiotic genes. These include the two nodPQ genes that help control the level of sulfated Nod factors.

\section{RESULTS}

\section{Identification, sequence, and mutation of syrM1.}

Initially, syrM1 was mapped to pNGR234a by partial sequencing of a cosmid clone that originated from subtractive hybridizations performed between NGR234 and the closely related $R$. fredii strain USDA257 (Perret et al. 1994). The second copy of syrM (syrM2) was only found when the complete sequence pNGR234a became available (Freiberg et al. 1997). syrM1 is more than $60 \%$ homologous to syrM2. Both are highly similar to the syrM genes of $R$. meliloti (Barnett and Long 1990) and R. leguminosarum bv. phaseoli (Michiels et al. 1993). The promoter region of syrM1 contains a putative Shine-Delgarno sequence, followed by two possible initiation codons. GeneMark predictions (Borodovsky et al. 1994) with all known syrM genes suggest that the first of these, a GTG, is the probable start codon. On this basis, the syrM1 open reading frame (ORF) is 1,014 bp in length, the deduced protein has 338 amino acids and a predicted molecular mass of approximately $37.5 \mathrm{kDa}$. A possible helix-turn-helix DNA-binding motif is present between residues 52 and 72 .
Mutation of $s y r M 1$ (giving NGR $\Delta s y r M 1$ ) was performed by deleting a 1.1-kb BamHI fragment (Fig. 1) and replacing it with the spectinomycin/streptinomycin resistant Omega interposon $\left(\Omega \mathrm{Sp}^{\mathrm{r}}\right)$ (see Materials and Methods). This BamHI fragment includes the first 107 amino acids of syrM1 as well as the upstream region, which contains no apparent ORF (Freiberg et al. 1997).

\section{SyrM1 is involved in activation of symbiotic genes.}

To test whether SyrM1 activates transcription of symbiotic genes, DNA from 23 cosmids selected to cover pNGR234a was used in a competitive RNA hybridization assay. Southern blots of these cosmids digested with XhoI were preincubated with nonlabeled RNA from apigenin-induced cultures of NGR $\Delta$ syrM1. Afterward, the blots were hybridized against ${ }^{32}$ P-labeled RNA from apigenin-induced NGR234 cultures. Autoradiography revealed several cosmids containing labeled fragments (Fig. 2), which could be grouped into two sets: one includes pXB285, pXB182, and pXBS4 and the other contains pXB740, pXB110, pXB64, and pXB368. Most of the genes present in these fragments are listed in Table 1. Some of them (such as $\mathrm{y} 4 \mathrm{yR}, \mathrm{y} 4 \mathrm{xI}$, and $\mathrm{y} 4 \mathrm{wF}$ ) share significant homologies with genes in data bases while others (such as y4yP, y4yQ, and $\mathrm{y} 4 \mathrm{gE}$ ) do not show homology with any known gene. It is worth noting that many of these fragments contain nod boxes.

Included among the genes under the control of syrM1 are nolB and nolW. Since they are divergently transcribed (Balatti et al. 1995; Freiberg et al. 1997), we attempted to verify this result by amplifying the intergenic region by polymerase chain reaction (PCR) and cloning it in both orientations in front of the promoterless lac $Z$ gene of pMP220 (see Materials and Methods). Afterward, the resulting plasmids pM220B and pM220W were transferred to NGR234 and NGR $\Delta$ syrM1 by tri-parental matings. Measurement of their $\beta$-galactosidase activities (Table 2) showed that both $n o l B$ and nolW are induced by apigenin, even though low but significant activities were detected under noninducing conditions (618 Miller Units $=$ MUs with pM220B). After $24 \mathrm{~h}$ of induction with apigenin, the activity of NGR234(pM220B) increased approximately eightfold, while the activity of NGR234(pM220W) went up nearly 14 times. Interestingly, the activity of the nol $W$ promoter was completely abolished in NGR $\Delta$ syrM 1 .

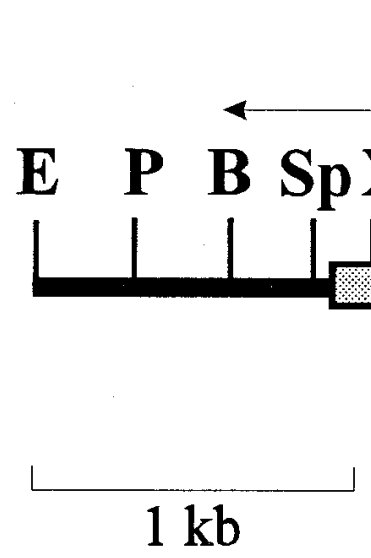

Fig. 1. Physical and genetic map of the $s y r M 1$ locus of Rhizobium sp. NGR234. Restriction sites are as follows: BamHI (B); BglII (Bg); ClaI (C); EcoRI (E); EcoRV (Ev); and HindIII (H). syrM1 was mutated by replacing the internal BamHI fragment by a spectinomycin-resistant Omega cassette and this is shown by $\Delta$. 
Mutation of syrM1 decreases production of sulfated Nod factors.

NGR234 and NGR $\Delta$ syrM1 were grown in RMM media supplemented with $\left[1-{ }^{14} \mathrm{C}\right]-\mathrm{D}-$ glucosamine. Apigenin was used to induce nod-gene expression. LCOs extracted from both supernatants were analyzed by reverse phase-thin layer chromatography (RP-TLC). NGR234 produces two major spots on RP-TLC (Fig. 3), the upper of which, spotB $\left(R_{f} \cong\right.$ $0.71)$ corresponds to sulfated molecules, while the lower, spotA $\left(R_{f} \cong 0.54\right)$ contains Nod factors that are either acetylated or nonsubstituted at the 2-O-methylfucose (Hanin et al.
1997). LCOs produced by NGR $\Delta$ syrM1 also separated into two spots, although the ratio of spotB/spotA decreased 10fold (determined by densitometric scanning of the corresponding autoradiographs). These data suggest that SyrM1 is required for the optimal production of sulfated Nod factors. Moreover, complementation of NGR $\Delta s y r M 1$ with the wild-type copy on a broad-host-range plasmid (pBR-syrMI) restored the ability of the transconjugants to produce sulfated molecules at the wild-type level (Fig. 3). Furthermore, a deletion downstream of $s y r M 1$ (deletion of the BglII fragment; Fig. 1) had no effect on levels of NodNGR[S] factors

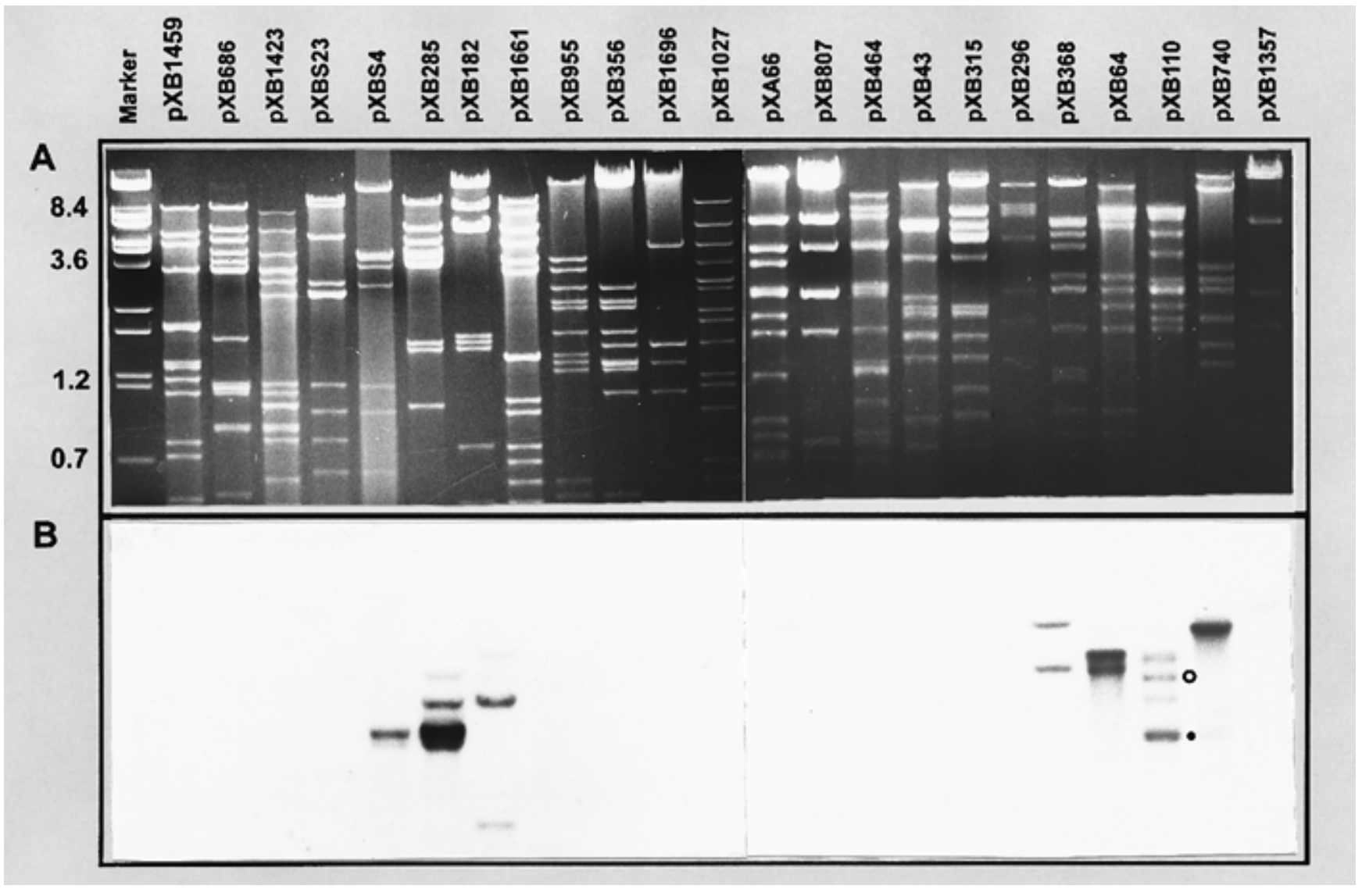

Fig. 2. A, Competitive RNA hybridization to a Southern blot of cosmid DNA (digested with XhoI) covering pNGR234a. B, Genes controlled by syrM1. Restriction digests of the 23 overlapping cosmids covering pNGR234a were transferred to Nylon membranes, and competitive hybridizations performed as described in Materials and Methods. Loci that are under the control of SyrM1 include nolWBTUV (open circle) and nolX (dark circle) genes. Lambda DNA digested with BstEII was used as the marker.

Table 1. Detection by competitive RNA hybridization of genes/open reading frames (ORFs) on pNGR234a that are under the control of $s y r M 1^{\mathrm{a}}$

\begin{tabular}{|c|c|c|c|c|}
\hline Cosmids & Size $(\mathbf{k b})$ & Signal & ORFs & putative promoter \\
\hline pXB740 & 10 & +++ & y4yP*, y4yQ*, y4yR,y4yS*, y4zA* & N.D \\
\hline pXB740/pXB110 & 2.3 & + & $h r c N, h r c Q, \mathrm{y} 4 \mathrm{yJ} *$ & N.D \\
\hline pXB110/pXB64 & 6.2 & + & y4xI, y4xK*, y4xL*, nodD2 & nod box \\
\hline pXB110 & 4.17 & ++ & nolWBTUV & Inducible promoter \\
\hline pXB110 & 3.2 & + & y4yA*, y4xO* & ND \\
\hline pXB110 & 2.2 & +++ & nolX & Inducible promoter? \\
\hline pXB64 & 6.5 & +++ & $\mathrm{y} 4 \mathrm{wM}$ & nod box \\
\hline pXB64 & 4.5 & +++ & $y 4 w F, y 4 w G^{*}, y 4 w E$ & nod box \\
\hline pXB368 & 4.7 & +++ & $\mathrm{y} 4 \mathrm{wD}, \mathrm{y} 4 \mathrm{wC}$ & N.D \\
\hline pXB182/pXB285 & 6.1 & +++ & $\mathrm{y} 4 \mathrm{hL} *, \mathrm{y} 4 \mathrm{hK} *, \mathrm{y} 4 \mathrm{hM}$ & nod box \\
\hline $\mathrm{pXB} 285 / \mathrm{pXBS} 4$ & $4.2,4.1,3.8$ & +++ & y $4 \mathrm{gE}^{*}, \mathrm{y} 4 \mathrm{gF}, \mathrm{y} 4 \mathrm{gH}, \mathrm{y} 4 \mathrm{gG}, \mathrm{y} 4 \mathrm{gI}, \mathrm{y} 4 \mathrm{gJ} *$ & nod box \\
\hline
\end{tabular}

${ }^{a}$ DNA fragments were produced by digestion of appropriate cosmids with XhoI. Intensity of hybridization signals detected on autoradiograms are designated as follows: +++ , strong; ++, medium; + , weak. Asterisks indicate genes coding for unknown functions. ND $=$ not determined. 
(data not shown), confirming that the observed phenotype is due to disruption of syrM1.

The most abundant of NodNGR[S] factors are N-acylated by either $\mathrm{C}_{18: 1}$ or $\mathrm{C}_{16: 1}$ fatty acids. Fast atom bombardmentmass spectrometric (FAB-MS) analysis of NodNGR[S] factors purified by reverse phase-high performance liquid chromatography (RP-HPLC) showed that the nonreducing $\mathrm{N}$ methylglucosamine contains zero, 1 , or 2 carbamates that gave, respectively, B1-ion fragments at $\mathrm{m} / \mathrm{z} 526,483$, and 440 $\left(\mathrm{C}_{18: 1} \mathrm{~N}\right.$-acylated LCOs) and B1-ion fragments at $\mathrm{m} / \mathrm{z} 498$, 455 , and $412\left(\mathrm{C}_{16: 1} \mathrm{~N}\right.$-acylated LCOs). This last fragmentation series was absent from sulfated LCOs produced by NGR $\Delta$ syrM1. On the other hand, the nonsulfated LCOs produced by both the wild-type and mutant strains were identical.

\section{How does SyrM1 control sulfation of LCOs?}

Genes required for sulfation of the reducing terminus of other LCOs have been described (Roche et al. 1991; Schwedock and Long 1992; Schwedock et al. 1994). nodP and nodQ code for enzymes responsible for the production of $3^{\prime}$ phosphoadenosine $5^{\prime}$-phophosulfate (PAPS), the activated sulfate donor. In $R$. meliloti, the sulfate group is transferred from PAPS to the reducing terminus of LCOs by the nodH gene product (Ehrhardt et al. 1995; Schultze et al. 1995).

Two unlinked nodPQ loci are located elsewhere in the genome of NGR234 (Perret et al. 1991), while a Nod factorspecific sulfotransferase (NoeE) is present on pNGR234a (Hanin et al. 1997). NoeE also uses PAPS as the sulfate donor (D. Quesada-Vincens, personal communication). As noeE is under the control of a flavonoid-inducible nod-box promoter (Hanin et al. 1997) and mutation of syrM1 drastically reduces the production of sulfated Nod factors, we asked whether SyrM1 is involved in the transcriptional activation of these sulfation genes. Plasmid pMPNBnoeE in which the nod box of noeE is transcriptionally fused to a promoterless lac $Z$ gene is carried on a broad-host-range plasmid, pMP220 (Spaink et al. 1987). When pMPNBnoeE was transferred into both the mutant and wild-type strains, apigenin ( $24 \mathrm{~h}$ exposure) induced similar activities in NGR $\Delta$ syrM1 (3,047 MUs) and NGR234 (3,085 MUs).

To test the effect of SyrM1 on expression of the nodPQ loci, we performed competitive RNA hybridization assays on Southern blots of three cosmids that contain the two nodPQ copies. Two overlapping cosmids, pXB559 and pXB1130, carry one copy of $n o d P Q$ (on a 3.1-kb EcoRI fragment) while the second is carried on a 4.3-kb EcoRI fragment of pXB1112. Competitive hybridization only labeled the 4.3-kb EcoRI fragment of pXB1112 (Fig. 4; the upper band corresponds to

Table 2. $\beta$-Galactosidase activity of NGR234 and NGR $\Delta s y r M 1$ harboring transcriptional fusions of $n o l B$ and $n o l W$ to a lac $Z$ reporter gene

\begin{tabular}{lcc}
\hline & \multicolumn{2}{c}{$\beta$-Galactosidase activity ${ }^{\mathbf{a}}$ (Miller units) } \\
\cline { 2 - 3 } Strains & Noninduced & Apigenin-induced \\
\hline NGR234(pMP220) & $52 \pm 8$ & $76 \pm 5$ \\
NGR234(pMP220 $)$ & $618 \pm 14$ & $4,811 \pm 102$ \\
NGR $\Delta$ syrM1(pMP220B) & $67 \pm 16$ & $2,087 \pm 74$ \\
NGR234(pMP220W) & $227 \pm 72$ & $3,146 \pm 164$ \\
NGR $\Delta$ syrM1(pMP220W) & $72 \pm 3$ & $109 \pm 40$ \\
\hline
\end{tabular}

a Values are the means \pm standard errors of triplicate assays. Cultures were induced during $24 \mathrm{~h}$ with $10^{-6} \mathrm{M}$ apigenin. the cosmid vector), suggesting that SyrM1 only activates one of the two copies of nodPQ.

\section{SyrM1 and host specificity.}

The influence of syrM1 on nodulation of several NGR234 hosts possessing both determinate and indeterminate nodules was tested. NGR $\Delta$ syrM1 produced fewer nodules than NGR234 on some hosts (Table 3), but the nodules formed on Flemingia congesta and Robinia pseudoacacia were less efficient in nitrogen fixation. Gas-chromatographic assays confirmed that nodules induced by NGR $\Delta$ syrM1 on Robinia pseudoacacia reduced approximately $40 \%$ less acetylene to ethylene $\left(7.6 \pm 0.3 \mu \mathrm{mol} \cdot \mathrm{h}^{-1} \cdot\right.$ plant $\left.^{-1}\right)$ than when plants were inoculated with NGR234 $\left(11.9 \pm 0.3 \mu \mathrm{mol} \cdot \mathrm{h}^{-1} \cdot\right.$ plant $\left.^{-1}\right)$.

\section{DISCUSSION}

In $R$. meliloti, syrM induces nod-gene expression via nodD3 and exo-gene expression via syrA (Mulligan and Long 1989; Maillet et al. 1990; Sharma and Signer 1990; Kondorosi et al. 1991a; Demont et al. 1994). As an example of this synergism, re-introduction of syrM together with nodD3 on a multicopy plasmid into $R$. meliloti results in high-level expression of inducible nod genes even in the absence of flavonoids.

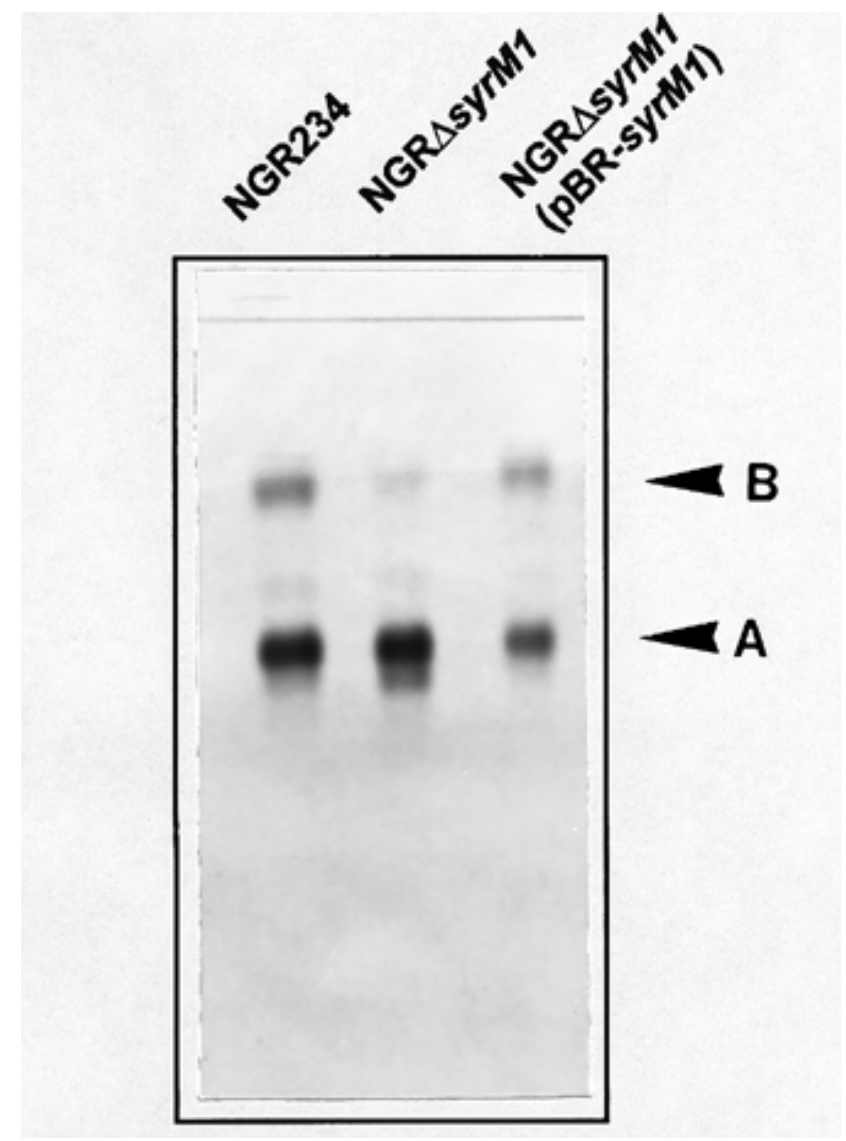

Fig. 3. Reverse phase-thin layer chromatography (RP-TLC) analysis of lipo-chitin-oligosaccharides (LCOs) purified from wild-type NGR234 and an syrM1 mutant (NGR $\Delta$ syrM1). Appropriate cultures were labeled with $\left[1-{ }^{14} \mathrm{C}\right]-\mathrm{D}$-glucosamine, and the RP-TLC exposed to X-ray film. Spots A and B indicate the position of nonsulfated and sulfated LCOs, respectively. 
Two copies of syrM, syrM1 and syrM2, are present on pNGR234a. RP-TLC analysis showed that an syrM1 mutant produced 10 times fewer sulfated Nod factors than the wild-type bacterium. Apparently this is because SyrM1 is involved in activation of one of the two copies of nodPQ. In R. meliloti, NodPQ are required for the synthesis of PAPS, the activated sulfate donor. This suggests that the decrease in sulfated Nod factors may be due to a diminution in the pool of PAPS available for Nod factor synthesis. Sulfation of $R$. tropici Nod factors was also found to be limited by the intra-cellular concentrations of activated sulfate (Poupot et al. 1995). Three times more sulfated NodNGR factors are acylated with $\mathrm{C}_{18: 1}$ than with $\mathrm{C}_{16: 1}$. As mutation of syrM1 causes an overall reduction in Nod factor production, it is likely that the amounts of sulfated LCOs $\mathrm{N}$ acylated by $\mathrm{C}_{16: 1}$ are reduced to undetectable levels.

Competitive RNA hybridizations showed that SyrM1 is also a transcriptional regulator of several plasmid-borne loci. Genes such as nolB and nolW that are under the control of SyrM1 are only expressed late in infection (Fellay et al. 1995). In apparent contradiction to the results of Freiberg et al. (1997), who did not detect any activity in the absence of the inducer, nolB is still expressed, albeit at low levels. Perhaps this is because the corresponding transcript pool is so small that it cannot be detected by RNA hybridization.

Together, these data show that syrM1 is involved both early in the symbiosis (in the production of sulfated Nod factors) and later during infection, suggesting that $s y r M 1$ is continuously expressed during these stages. Several genes (but not nolXWBTUV) seem to be under the control of nod-box promoters and SyrM1 might interact directly or indirectly (via another

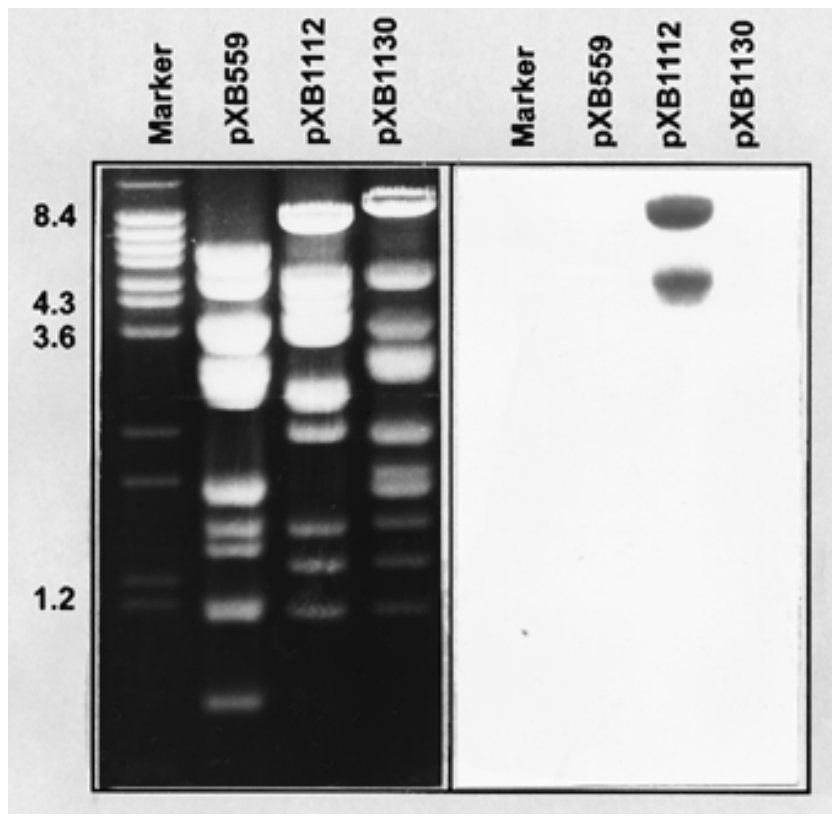

Fig. 4. Competitive RNA hybridization to a Southern blot of cosmid DNA covering the two chromosomal copies of the nodPQ genes of $R h i$ zobium sp. NGR234. Left, ethidium bromide-stained DNA of cosmids digested with EcoRI, and separated on a $1 \%$ (wt/vol) agarose gel. Right, autoradiograph obtained after hybridization with competitor RNA isolated from NGR $\Delta s y r M 124 \mathrm{~h}$ after induction with $10^{-6} \mathrm{M}$ apigenin. The blot was probed with ${ }^{32} \mathrm{P}$-labeled RNA isolated from NGR234 induced under the same conditions. Lambda DNA digested with BstEII was used as the marker regulator) with them. As syrM1 of $R$. meliloti needs nodD3 to co-regulate nod-gene expression, syrM1 of NGR234 may need other regulator(s). NodD1 is required for the induction of many of these genes (Fellay et al. 1995), and a regulatory cascade involving nodD1 and syrM1 may activate a number of symbiotic genes. Alternatively, syrM 1 could act cooperatively with nodD 1 to ensure optimal expression of these genes.

Regulation of syrM1 itself has proven more difficult to study. Several transcriptional fusions between lac $Z$ and the $5^{\prime}$ region of $s y r M 1$ were constructed but none permitted detection of $\beta$-galactosidase activity (data not shown). Similar, negative results were obtained with $s y r M$ of $R$. meliloti (Sharma and Signer 1990). Mutations in syrM1 of NGR234 (this work) or syrM of $R$. meliloti (Barnett and Long 1990) have only minor effects on nodulation. One possibility is that syrM1 might ensure a network of regulation whose biological role is to optimize factors controlling efficient nodulation and specific recognition between the symbiotic partners. A second copy of syrM also exists: syrM2 may mask or complement the function of $s y r M 1$. In contrast, syrM2 is under the control of a nod-box promoter and is induced by flavonoids (Freiberg et al. 1997). We are currently investigating the effects of single and multiple mutations in these regulators and their effects on host-specific nodulation.

\section{MATERIALS AND METHODS}

Media, growth conditions, and bacterial matings.

Bacterial strains and plasmids used in this study are listed in Table 4. Rhizobium strains were grown at $27^{\circ} \mathrm{C}$ on $\mathrm{RMM}$ medium (Broughton et al. 1986) containing succinate as the carbon source. Apigenin was added at $10^{-6} \mathrm{M}$. Antibiotics were added at the following concentrations: gentamycin $(\mathrm{Gm})$, $15 \mu \mathrm{g} \cdot \mathrm{ml}^{-1}$; rifampicin (Rif) and spectinomycin (Sp), $100 \mu \mathrm{g} \cdot$ $\mathrm{ml}^{-1}$; and tetracycline (Tc), $25 \mu \mathrm{g} \cdot \mathrm{ml}^{-1}$. Broad-host-range plasmids were mobilized from Escherichia coli DH5 $\alpha$ into Rhizobium by tri-parental matings with the helper plasmid pRK2013 (Ditta et al. 1980).

\section{Construction of an syrM1 mutant.}

A 5.3-kb HindIII-EcoRI fragment containing syrM1 obtained from the cosmid pXB807 was cloned into pBluescript

Table 3. Average numbers of nodules formed on plants following inoculation with NGR234 or NGR $\Delta s y r M 1^{\mathrm{a}}$

\begin{tabular}{lcc}
\hline Plant $^{\text {b,c }}$ & NGR234 & NGR $\Delta$ syrM1 \\
\hline Cajanus cajan & $14 \pm 1$ & $13 \pm 2$ \\
Calopogonium caeruleum & $13 \pm 2$ & $9 \pm 1$ \\
Desmodium intortum & $19 \pm 2$ & $17 \pm 1$ \\
Flemingia congesta & $21 \pm 2$ & $18 \pm 1$ \\
Lablab purpureus & $35 \pm 1$ & $29 \pm 1$ \\
Leucaena leucocephala & $15 \pm 2$ & $15 \pm 2$ \\
Macroptilium atropurpureum & $31 \pm 1$ & $20 \pm 4$ \\
Pachyrhizus tuberosus & $5 \pm 1.0$ & $4 \pm 1.5$ \\
Psophocarpus palustris & $5 \pm 0.9$ & $5 \pm 1.2$ \\
Robinia pseudoacacia & $5 \pm 0.5$ & $4 \pm 1.2$ \\
Tephrosia vogeli & $22 \pm 2$ & $14 \pm 2$ \\
Vigna unguiculata & $32 \pm 2$ & $30 \pm 2$ \\
\hline
\end{tabular}

${ }^{a}$ Mean value for 16 to 24 plants. Standard deviations are indicated.

${ }^{\mathrm{b}}$ Plants were harvested 6 weeks after inoculation.

${ }^{\mathrm{c}}$ Botanical names and sources of seeds from S. G. Pueppke and W. J. Broughton (unpublished). 
$\mathrm{SK}^{+}$, which was linearized with the same enzymes. Then, this fragment (p807HEX) was digested with SpeI-ApaI and cloned into the SpeI-ApaI sites of the suicide vector pJQ200 SK (Quandt and Hynes 1993) to give pJQ807HEX. Digestion of pJQ807HEX with BamHI results in deletion of an internal $1.1-\mathrm{kb}$ fragment of the $s y r M 1$ gene (the BamHI site in the polylinker was deleted after SpeI-ApaI digestion). A Sp ${ }^{\mathrm{r}}$ Omega interposon (Prentki and Krisch 1984) was ligated into this deleted construct (pJQ $\Delta \mathrm{BH} 1.1)$. pJQ200SK carries the $s a c B$ gene of Bacillus subtilis, which is inducible by sucrose and lethal when expressed in gram-negative bacteria. The recombinant plasmid was then mobilized into NGR234 with triparental matings as described above. Transconjugants were selected and purified on RMM plates containing Rif (100 $\mu \mathrm{g}$. $\mathrm{ml}^{-1}$ and $\mathrm{Sp}\left(100 \mu \mathrm{g} \cdot \mathrm{ml}^{-1}\right)$. Single colonies were grown in liquid RMM and spread on plates containing both antibiotics and 5\% (wt/vol) sucrose. Marker exchange by double crossover giving NGR $\Delta$ syrM 1 was confirmed by Southern transfer analysis.

\section{Plant assays.}

Nodulation tests were performed in Magenta jars as described previously (Lewin et al. 1990). All plants were grown at a day temperature of $28^{\circ} \mathrm{C}$, a night temperature of $18^{\circ} \mathrm{C}$, and a light phase of $16 \mathrm{~h}$. Acetylene reduction assays on Robinia pseudoacacia were performed as described previously (Williams and Broughton 1979).

RNA extraction, labeling, and competitive hybridizations.

Rhizobium cultures were harvested at an optical density $\left(A_{600}\right)$ of 0.4 to 0.6 and the RNA extracted as described previously (Fellay et al. 1995). Radioactively labeled RNA probes $(10 \mu \mathrm{g})$ were prepared as follows: total NGR234 RNA was partially digested by treatment with $0.125 \mathrm{M} \mathrm{NaOH}$ for 25 min on ice. Terminal, $5^{\prime}$ labeled fragments were prepared by incubating probe RNA with T4 polynucleotide kinase and $[\gamma$ ${ }^{32} \mathrm{P}$ ]-ATP for $90 \mathrm{~min}$ at $37^{\circ} \mathrm{C}$. Finally, labeled RNA was separated from the unreacted components of the reaction mixture by passage through a Sephadex G50 column (Pharmacia Fine Chemicals, Uppsala, Sweden).

Competitive hybridizations were performed on GeneScreen Plus Nylon membranes (NEN Research Products, Boston,
MA) containing digested cosmid DNA (Fellay et al. 1995). Unlabeled RNA $(100 \mu \mathrm{g})$ from NGR $\Delta s y r M 1$-induced cultures was used for prehybridization (as competitor RNA) and $10 \mu \mathrm{g}$ of labeled RNA extracted from NGR234-induced cultures was added as the probe.

\section{Cloning and expression of the nolB-nolW intergenic region.}

Two primers designed to amplify the $n o l B /$ nol $W$ intergenic region-IBW1: 5'GGGGAGACTGTTAGAGATTG3'; IBW3: 5'GCAACGCGGCAGAGAGATCC3' - were synthesized. Together with the cosmid pXB110 (which contains the nolXWBTUV locus), these primers were used to amplify the intergenic region between $n o l B$ and $n o l W$. Reactions were performed in a final volume of $50 \mu \mathrm{l}$ containing $1 \mathrm{mM}$ of each primer, $0.1 \mathrm{mM}$ deoxynucleosides triphosphates, $1 \times$ thermophilic DNA buffer supplemented with $1.5 \mathrm{mM} \mathrm{MgCl}_{2}$ and 1 unit Taq DNA polymerase. Cycles (35) at $94^{\circ} \mathrm{C}$ for $30 \mathrm{~s}, 52^{\circ} \mathrm{C}$ for $45 \mathrm{~s}$, and $72^{\circ} \mathrm{C}$ for $30 \mathrm{~s}$ were followed by incubation at $72^{\circ} \mathrm{C}$ for $5 \mathrm{~min}$. A 360 -pb PCR product was cloned into both the EcoRV-XbaI sites of pBluescript $\mathrm{KS}^{+}$and the SmaI-XbaI sites of pBluescript $\mathrm{SK}^{+}$. Both products were then cloned into pMP220, the first as a KpnI-XbaI fragment and the second as an XbaI-PstI fragment generating pM220W (carrying the nolW promoter) and $\mathrm{pM} 220 B$ (carrying the $n o l B$ promoter), respectively. Rhizobium strains containing pM220W or pM220B were grown in RMM media supplemented with $25 \mathrm{mg} \cdot \mathrm{ml}^{-1}$ tetracycline. When the optical density $\left(A_{600}\right)$ reached 0.1 , apigenin was added to a final concentration of $10^{-6} \mathrm{M}$. Levels of $\beta$-galactosidase were measured according to Miller (1972).

\section{Purification of Nod factors.}

Rhizobia were raised at $27^{\circ} \mathrm{C}$ in $\mathrm{RMM}$ medium with or without $10^{-6} \mathrm{M}$ apigenin (Price et al. 1992). Cells were grown to an $A_{600}$ of 1 . After centrifugation $\left(7,000 \times g, 30 \mathrm{~min}, 4^{\circ} \mathrm{C}\right)$, extracellular Nod factors were extracted from the supernatant and purified by RP-HPLC as described previously (Price et al. 1992; Jabbouri et al. 1995).

\section{Analytical methods.}

Rhizobium cultures were made radioactive by addition of $\left[1-{ }^{14} \mathrm{C}\right]$-D-glucosamine $(54 \mathrm{mCi} / \mathrm{mmol})$ to the culture medium

Table 4. Rhizobium strains and plasmids used in this study

\begin{tabular}{|c|c|c|}
\hline Strains/plasmids & Characteristics $^{\mathbf{a}}$ & Source/reference \\
\hline \multicolumn{3}{|l|}{ Strains } \\
\hline NGR234 & Rif $^{\mathrm{T}}$ derivative of wild-type strain NGR234 from Lablab purpureus & Stanley et al. 1988 \\
\hline NGRAsyrM1 & syrM1 deletion mutant, $\operatorname{Rif}^{\mathrm{r}} \mathrm{Sp}^{\mathrm{r}}$ & This work \\
\hline \multicolumn{3}{|l|}{ Plasmids } \\
\hline pBluescript-KS ${ }^{+}$ & $A m p^{r}$ & Stratagene, La Jolla, CA \\
\hline pBluescript-SK ${ }^{+}$ & $A m p^{r}$ & Stratagene \\
\hline pJQ200 SK & pACYC184-derived (p15A) suicide vector, $\mathrm{Gm}^{\mathrm{r}}$ & Quandt and Hynes 1993 \\
\hline pMP220 & IncP $P$ expression vector containing a promoterless $l a c Z$ gene, $\mathrm{Tc}^{\mathrm{r}}$ & Spaink et al. 1987 \\
\hline PMPNBnoeE & $960 \mathrm{bp}$ HindIII-SphI fragment containing the nod box of noeE cloned in pMP220 & Hanin et al. 1997 \\
\hline pM220B & $\begin{array}{l}\text { Polymerase chain reaction (PCR) fragment containing the nolB promoter cloned in XbaI- } \\
\text { PstI sites of pMP220 }\end{array}$ & This work \\
\hline pM220W & $\begin{array}{l}\text { Polymerase chain reaction fragment containing the nolW promoter cloned in } K p n \mathrm{I}-\mathrm{Xba \textrm {I }} \\
\text { sites of pMP220 }\end{array}$ & This work \\
\hline pBBR1-MCS5 & Broad-host-range cloning vector, $\mathrm{Gm}^{\mathrm{r}}$ & Kovach et al. 1994 \\
\hline pBR-syrM1 & A 5.6-kb HindIII-EcoRI fragment containing syrM1 cloned in pBBR1-MCS5 & This work \\
\hline pRK2013 & ColE1 replicon with RK2 tra genes, $\mathrm{Nm}^{\mathrm{r}} \mathrm{Km}^{\mathrm{r}}$ & Figurski and Helinski 1979 \\
\hline
\end{tabular}

${ }^{a} \mathrm{Amp}^{\mathrm{r}}$, ampicillin, $\mathrm{Gm}^{\mathrm{r}}$, gentamycin, $\mathrm{Km}^{\mathrm{r}}$, kanamycin, $\mathrm{Rif}^{\mathrm{r}}$, rifampicin, $\mathrm{Sp}^{\mathrm{r}}$ spectinomycin, $\mathrm{Tc}^{\mathrm{r}}$, tetracycline, and $\mathrm{Nm}^{\mathrm{r}}$, neomycin, resistance. 
and grown to the exponential phase. After centrifugation, the supernatant was applied to a $\mathrm{C}_{18}$ reverse-phase Sep-Pak (Millipore, Milford, MA), and the columns rinsed with $5 \mathrm{ml}$ of $\mathrm{H}_{2} \mathrm{O}$. Nod factors were eluted with $5 \mathrm{ml}$ of methanol and, after vacuum drying were dissolved in methanol and applied to TLC plates $\left(C_{18}\right.$ reverse phase-high performance thin layer chromatography, RP-HPTLC; Aldrich-Chemical, GillinghamDorset, UK). Development was performed with 9:1 (vol/vol) methanol/5.5 $\mathrm{M}$ ammonia as the running solvent. Mass spectra were recorded on an Autospec instrument (Fisons, VGAnalytical, Manchester, U.K.) fitted with a caesium-ion gun working at $20 \mathrm{kV}$. The acceleration voltage was $8 \mathrm{kV}$. A 1:1 mixture of meta-nitrobenzyl alcohol and glycerol was used as the matrix. Matrices were acidified with $0.1 \mathrm{M}$ trifluoroacetic acid, or spiked with $10 \%$ sodium iodide for use in the positive-ionization mode.

\section{ACKNOWLEDGMENTS}

We wish to thank Dora Gerber and Slobodan Relić for their help with many aspects of this work. We are grateful to D. Promé for mass spectra. Financial assistance was provided by the Swiss National Science Foundation (projects 31-36454.92 and 31-45921.95) and the Université de Genève.

\section{LITERATURE CITED}

Balatti, P. A., Kovács, L. G., Krishnan, H. B., and Pueppke, S. G. 1995. Rhizobium sp. NGR234 contains a functional copy of the soybean cultivar specificity locus, nolXWBTUV. Mol. Plant-Microbe Interact. 8:693-699.

Barnett, M. J., and Long, S. R. 1990. DNA sequence and translational product of a new nodulation regulatory locus: SyrM has sequence similarity to NodD proteins. J. Bacteriol. 172:3695-3700.

Bellato, C. M., Balatti, P. A., Pueppke, S. G., and Krishnan, H. 1996. Proteins from cells of Rhizobium fredii bind to DNA sequences preceding nolX, a flavonoid-inducible nod gene that is not associated with a nod box. Mol. Plant-Microbe Interact. 9:457-463.

Borodovsky, M., Rudd, K. E., and Koonin, E. V. 1994. Intrinsic and extrinsic approaches for detecting genes in a bacterial genome. Nucleic Acids Res. 22:4756-4767.

Broughton, W. J., Wong, C.-H., Lewin, A., Samrey, U., Myint, H., Meyer z. A., H., Dowling, D. N., and Simon, R. 1986. Identification of Rhizobium plasmid sequences involved in recognition of Psophocarpus, Vigna, and other legumes. J. Cell Biol. 102:1173-1182.

Cren, M., Kondorosi, A., and, Kondorosi, E. 1995. NolR controls expression of the Rhizobium meliloti nodulation genes involved in the core Nod factor synthesis. Mol. Microbiol. 15:733-747.

Demont, N., Ardourel, M., Maillet, D., Promé, D., Ferro, M., Promé, J.C., and Dénarié, J. 1994. The Rhizobium meliloti regulatory nodD3 and $s y r M$ genes control the synthesis of a particular class of nodulation factors $N$-acylated by $(\omega-1)$-hydroxylated fatty acids. EMBO J. 13:2139-2149.

Dénarié, J., Debellé, F., and Promé, J.-C. 1996. Rhizobium lipo-chitooligosaccharide nodulation factors: Signaling molecules mediating recognition and morphogenesis. Annu. Rev. Biochem. 65:503-535.

Ditta, G., Stanfield, S., Corbin, D., and Helsinki, D. R. 1980. Broad host range DNA cloning system for gram-negative bacteria: Construction of a gene bank of Rhizobium meliloti. Proc. Natl. Acad. Sci. USA 77: 7347-7351.

Ehrhardt, D. W., Atkinson, E. M., Faull, K. F., Freedberg, D. I., Sutherlin, D. P., Armstrong, R., and Long, S. R. 1995. In vitro sulfotransferase activity of NodH, a nodulation protein of Rhizobium meliloti required for host-specific nodulation. J. Bacteriol. 177:6237-6245.

Fellay, R., Hanin, M., Montorzi, G., Frey, J., Freiberg, C., Golinowski, W., Staehelin, C., Broughton, W. J., and Jabbouri, S. 1998. nodD2 of Rhizobium sp. NGR234 is involved in the repression of the nodABC operon. Mol. Microbiol. 27:1039-1050.

Fellay, R., Perret, X., Viprey, V., Broughton, W. J., and Brenner, S. 1995.
Organisation of host-inducible transcripts on the symbiotic plasmid of Rhizobium sp. NGR234. Mol. Microbiol. 16:657-667.

Figurski, D. H., and Helinski, D. R. 1979. Replication of an origincontaining derivative of plasmid RK2 dependent on a plasmid function provided in trans. Proc. Natl. Acad. Sci. USA 76:1648-1652.

Fisher, R. F., and Long, S. R. 1993. Interactions of NodD at the nod box: NodD binds to two distinct sites on the same face of the helix and induces a bend in the DNA. J. Mol. Biol. 233:336-348.

Freiberg, C., Fellay, R., Bairoch, A., Broughton, W. J., Rosenthal, A., and Perret, X. 1997. Molecular basis of symbiosis between Rhizobium and legumes. Nature 387:394-401.

Garcia, M., Dunlap, J., Loh, J., and Stacey, G. 1996. Phenotype characterization and regulation of the nolA gene of Bradyrhizobium japonicum. Mol. Plant-Microbe Interact. 9:625-635.

Györgypal, Z., Kondorosi, E., and Kondorosi, A. 1991. Diverse signal sensitivity of NodD protein homologs from narrow and broad host range rhizobia. Mol. Plant-Microbe Interact. 4:356-364.

Hanin, M., Jabbouri, S., Broughton, W. J., Fellay, R., and QuesadaVincens, D. Molecular aspects of host-specific nodulation. In: PlantMicrobe Interactions 4. G. Stacey and N. T. Keen, eds. American Phytopathological Society, St. Paul, MN. (In press.)

Hanin, M., Jabbouri, S., Quesada-Vincens, D., Freiberg, C., Perret, X., Promé, J.-C., Broughton, W. J., and Fellay, R. 1997. Sulphation of Rhizobium sp. NGR234 Nod factors is dependent on noeE, a new host specificity gene. Mol. Microbiol. 24:1119-1129.

Henikoff, S., Haughn, G. W., Calvo, J. M., and Wallace, J. C. 1988. A large family of bacterial activator proteins. Proc. Natl. Acad. Sci. USA 85:6602-6606.

Jabbouri, S., Fellay, R., Talmont, F., Kamalaprija, P., Burger, U., Relić, B., Promé, J.-C., and Broughton, W. J. 1995. Involvement of nodS in $\mathrm{N}$-methylation and nodU in 6-O-carbamoylation of Rhizobium sp. NGR234 Nod factors. J. Biol. Chem. 270:22968-22973.

Kondorosi, E., Buiré, M., Cren, M., Iyer, N., Hoffmann, B., and Kondorosi, A. 1991a. Involvement of the syrM and nodD3 genes of Rhizobium meliloti in nod gene activation and in optimal nodulation of the plant host. Mol. Microbiol. 5:3035-3048.

Kondorosi, E., Pierre, M., Cren, M., Haumann, U., Schell, J., and Kondorosi, A. 1991b. Identification of NolR, a negative transacting factor controlling the nod regulon in Rhizobium meliloti. J. Mol. Biol. 222: 885-896.

Kovach, M. E., Phillips, R. W., Elzer, P. H., Roop, R. M., and Peterson, K. M. 1994. pBBR1MCS: A broad-host-range cloning vector. Biotechniques 16:800-802.

Kovács, L. G., Balatti, P. A., Krishnan, H., and Pueppke, S. G. 1995. Transcriptional organization and expression of nolXWBTUV, a locus that regulates cultivar-specific nodulation of soybean by Rhizobium fredii USDA257. Mol. Microbiol. 17:923-933.

Le Strange, K. K., Bender, G. L., Djordjevic, M. A., Rolfe, B. G., and Redmond, J. W. 1990. The Rhizobium strain NGR234 nodD1 gene product responds to activation by the simple phenolic compounds vanillin and isovanillin present in wheat seedling extracts. Mol. PlantMicrobe Interact. 3:214-220.

Lerouge, P., Roche, P., Faucher, C., Maillet, F., Truchet, G., Promé, J.C., and Dénarié, J. 1990. Symbiotic host-specificity of Rhizobium meliloti is determined by a sulphated and acylated glucosamine oligosaccharide signal. Nature 344:781-784.

Lewin, A., Cervantes, E., Wong, C.-H., and Broughton, W. J. 1990. nodSU, two new nod genes of the broad host range Rhizobium strain NGR234 encode host-specific nodulation of the tropical tree Leucaena leucocephala. Mol. Plant-Microbe Interact. 3:317-326.

Loh, J., Garcia, M., and Stacey, G. 1997. NodV and NodW, a second flavonoid recognition system regulating nod gene expression in Bradyrhizobium japonicum. J. Bacteriol. 179:3013-3020.

Maillet, F., Debellé, F., and Dénarié, J. 1990. Role of the nodD and syrM genes in the activation of the regulatory gene $\operatorname{nodD} 3$, and of the common and host-specific nod genes of Rhizobium meliloti. Mol. Microbiol. 4:1975-1984.

Mergaert, P., van Montagu, M., and Holsters, M. 1997. Molecular mechanisms of Nod factor diversity. Mol. Microbiol. 25:811-817.

Michiels, J., De Wilde, P., and Vanderleyden, J. 1993. Sequence of the Rhizobium leguminosarum biovar phaseoli syrM gene. Nucleic Acids Res. 21:3893.

Miller, J. H. 1972. Experiments in Molecular Genetics. 1st ed. Cold Spring Harbor Laboratory, Cold Spring Harbor, New York. 
Mulligan, J. T., and Long, S. R. 1989. A family of activator genes regulates expression of Rhizobium meliloti nodulation genes. Genetics 122:7-18

Perret, X., Broughton, W. J., and Brenner, S. 1991. Canonical ordered cosmid library of the symbiotic plasmid of Rhizobium species NGR234. Proc. Natl. Acad. Sci. USA 88:1923-1927.

Perret, X., Fellay, R., Bjourson, A. T., Cooper, J. E., Brenner, S., and Broughton, W. J. 1994. Subtraction hybridisation and shot-gun sequencing: A new approach to identify symbiotic loci. Nucleic Acids Res. 22:1335-1341.

Poupot, R., Martinez-Romero, E., Maillet, F., and Promé, J.-C. 1995. Rhizobium tropici nodulation factor sulfation is limited by the quantity of activated form of sulfate. FEBS Lett. 368:536-540.

Prentki, P., and Krisch, H. M. 1984. In vitro insertional mutagenesis with a selectable DNA fragment. Gene 29:303-313.

Price, N. P. J., Relić, B., Talmont, F., Lewin, A., Promé, D., Pueppke, S. G., Maillet, F., Dénarié, J., Promé, J.-C., and Broughton, W. J. 1992. Broad-host-range Rhizobium species NGR234 secretes a family of carbamoylated, and fucosylated, nodulation signals that are $O$ acetylated or sulphated. Mol. Microbiol. 6:3575-3584.

Quandt, J., and Hynes, M. F. 1993. Versatile suicide vectors allow direct selection for gene replacement in Gram-negative bacteria. Gene 127: 15-21.

Relić, B., Fellay, R., Lewin, A., Perret, X., Price, N. P. J., Rochepeau, P., and Broughton, W. J. 1993a. nod genes and nod factors of Rhizobium species NGR234. Pages 183-189 in: New Horizons in Nitrogen Fixation. R. Palacios, J. Mora, and W. E. Newton, eds. Kluwer Academic Publishers, Dordrecht, The Netherlands.

Relić, B., Talmont, F., Kopcinska, J., Golinowski, W., Promé, J.-C., Broughton, W. J. 1993b. Biological activity of Rhizobium sp. NGR234 Nod-factors on Macroptilium atropurpureum. Mol. PlantMicrobe Interact. 6:764-774.

Roche, P., Debellé, F., Maillet, F., Lerouge, P., Faucher, C., Truchet, G., Dénarié, J. and Promé, J.-C. 1991. Molecular basis of symbiotic host specificity in Rhizobium meliloti: nodH and nodPQ genes encode the sulfation of lipo-oligosaccharide signals. Cell 67:1131-1143.

Sanjuan, J., Grob, P., Göttfert, M., Hennecke, H., and Stacey, G. 1994.
NodW is essential for full expression of the common nodulation genes in Bradyrhizobium japonicum. Mol. Plant-Microbe Interact. 7:364369.

Schultze, M., and Kondorosi, A. 1996. The role of lipochitooligosaccharides in root nodule organogenesis and plant cell growth. Curr. Opin. Genet. Dev. 6:631-638.

Schultze, M., Staehelin, C., Röhrig, H., John, M., Schmidt, J., Kondorosi, E., Schell, J., and Kondorosi, A. 1995. In vitro sulfotransferase activity of Rhizobium meliloti NodH protein: Lipochitooligosaccharide nodulation signals are sulfated after synthesis of the core structure. Proc. Natl. Acad. Sci. USA 92:2706-2709.

Schwedock, J. S., Liu, C., Leyh, T. S., and Long, S. R. 1994. Rhizobium meliloti NodP and NodQ form a multifunctional sulfate-activating complex requiring GTP for activity. J. Bacteriol. 176:7055-7064.

Schwedock, J. S., and Long, S. R. 1992. Rhizobium meliloti genes involved in sulfate activation: The two copies of $\operatorname{nodPQ}$ and a new locus, saa. Genetics 132:899-909.

Sharma, S. B., and Signer, E. R. 1990. Temporal and spatial regulation of the symbiotic genes of Rhizobium meliloti in planta revealed by transposon Tn5-gusA. Genes Dev. 4:344-356.

Spaink, H. P. 1996. Regulation of plant morphogenesis by lipo-chitin oligosaccharides. Crit. Rev. Plant Sci. 15:559-582.

Spaink, H. P., Okker, R. J. H., Wijffelman, C. A., Pees, E., and Lugtenberg, B. J. J. 1987. Promoters in the nodulation region of the Rhizobium leguminosarum Sym plasmid pRL1JI. Plant Mol. Biol. 9:27-39.

Stanley, J., Dowling, D. N., and Broughton, W. J. 1988. Cloning of hemA from Rhizobium sp. NGR234 and symbiotic phenotype of a gene-directed mutant in diverse legume genera. Mol. Gen. Genet. 215:32-37.

Truchet, G., Roche, P., Lerouge, P., Vasse, J., Camut, S., de Billy, F., Promé, J.-C., and Dénarié, J. 1991. Sulphated lipo-oligosaccharide signals of Rhizobium meliloti elicit root nodule organogenesis in alfalfa. Nature 351:670-673.

Williams, W. M., and Broughton, W. J. 1979. Measurement of acetylene reduction in various systems. Pages 289-339 in: Soil Microbiology and Plant Nutrition. W. J. Broughton, C. K. John, J. C. Rajarao, and B. Lim, eds. The University of Malaya Press, Kuala Lumpur, Malaya. 